\title{
ANALISIS BREAK EVEN POINT TERNAK SAPI POTONG \\ KELOMPOK TANI "SUMBER HIDUP SEJATI" \\ DI KECAMATAN BINTAUNA KABUPATEN \\ BOLAANG MONGONDOW UTARA
}

\author{
Alvianti Bawinto, D.R. Mokoagouw, F.H. Elly*, M.A.V. Manese
}

Fakultas Peternakan Universitas Sam Ratulangi, Manado 95115

\begin{abstract}
ABSTRAK
Ternak sapi di Bolaang Mongondow Utara merupakan salah satu sumber pendapatan masyarakat. Permasalaannya belum diketahui kelayakan usaha ternak sapi potong milik kelompok tani ternak sapi Sumber Hidup Sejati. Tujuan penelitian ini adalah untuk mengetahui Break Even Point (BEP) usaha ternak sapi potong pada kelompok tani "Sumber Hidup Sejati". Penelitian ini dilakukan dengan menggunakan metode studi kasus. Data primer diperoleh langsung dari responden melalui wawancara dengan menggunakan kuesioner. Data sekunder diperoleh dari instansi yang terkait dengan penelitian ini. Total biaya variabel yang dikeluarkan Rp 86.444.000, biaya tetap sebesar Rp 6.280.000 dengan penerimaan Rp 105.000.000. Hasil penelitian menunjukkan jumlah ternak sapi sebanyak 14 ekor dengan keuntungan sebesar Rp. 14.276.000. Hasil analisis Break Even Point (BEP) penerimaan diperoleh nilai 34.888.889. Artinya usaha ternak sapi potong pada kelompok tani "Sumber Hidup Sejati" mencapai pulang pokok pada saat memperoleh penerimaan sebesar Rp. 34.888.889,-. Berdasarkan hasil analisis BEP volume diperoleh nilai BEPnya sebesar 4,74. Artinya usaha ternak sapi potong pada kelompok tani "Sumber Hidup Sejati" mencapai pulang pokok apabila memelihara sapi potong sebanyak 5 ekor.
\end{abstract}

Kata Kunci: Break Even Point, Ternak Sapi Potong, Kelompok Tani

\footnotetext{
*Korespondensi (corresponding author):
}

Email: femi_elly@yahoo.co.id

\begin{abstract}
ANALYSIS OF BREAK EVEN POINT ON CATTLE FARMING BY FARMER GROUP "SUMBER HIDUP SEJATI" IN THE SUB DISTRICT OF BINTAUNA BOLAANG MONGONDOW NORTH. Cattle, in Bolaang Mongondow North is one of the sources of income of the community. The problem, unknown feasibility of cattle, by the groups "Sumber Hidup Sejati" as the owner. The purpose of research that has been done is to analyze Break Even Point (BEP) of the cattle business, the farmer group " Sumber Hidup Sejati". This research has been conducted using the case study method. Primary data was obtained directly from the respondent, through interviews using a questionnaire. Secondary data were obtained from the agency, which is associated with this research. Total variable cost of Rp 86.444 million, fixed costs USD 6.28 million, with income from sales of cattle Rp 105,000,000. The results showed the number as many as 14 heads of cattle, with a profit of Rp. 14.276 million. The results of the analysis of Break Even Point (BEP) for the revenue of cattle obtained value $34,888,889$. That is the business of cattle on farmers' groups "Sumber Hidup Sejati" reached break even, on the condition of the revenues received Rp. $34,888,889$, Based on the analysis BEP volume values obtained BEP 4.74. That is the business of cattle on farmers' groups "Sumber Hidup Sejati" no profit no loss suffered if livestock raising cattle that are as much as five head.
\end{abstract}

Keywords: Break Even Point, Beef Cattle, Farmers Group 


\section{PENDAHULUAN}

Sub sektor peternakan merupakan salah satu bagian dari sektor pertanian yang memiliki peranan penting dalam menunjang kebutuhan pangan masyarakat. Salah satu usaha peternakan yang dapat menunjang kebutuhan masyarakat akan protein hewani asal ternak ialah produk daging sapi, ternak sapi bermanfaat memenuhi kebutuhan protein hewani asal ternak yang esensial guna memenuhi kebutuhan gizi masyarakat (kesehatan) serta menambah sumber pendapatan petani peternak baik sebagai usaha sampingan maupun usaha utama dan juga ternak sapi sebagai salah satu sumber tenaga kerja.

Usaha sapi potong sangat berperan dalam kehidupan penduduk pedesaan pada skala kecil terbukti mampu membantu pendapatan dengan pemanfaatan sumberdaya alam yang tersedia di sekitarnya. Usaha ternak sapi menurut Yulianto dan Saparinto (2011), memiliki prospek usaha masa depan. Ternak sapi juga sebagai tambahan penghasilan, dan kotorannya dapat dijadikan sebagai sumber pupuk yang sekaligus memberikan keuntungan bagi petani. Tantangan terbesar dalam semua system produksi ternak di berbagai Negara berkembang adalah pakan dan lahan, Padahal faktor utama dalam menentukan produktivitas

ternak sapi potong adalah terjaminnya ketersediaan hijuan pakan (Abdullah et al., 2005).

Daging sapi potong merupakan sumber protein hewani yang banyak disukai oleh masyarakat Indonesia. Kenyataannya ketersediaan daging sapi saat ini belum mampu untuk memenuhi kebutuhan masyarakat. Hal ini yang menyebabkan sebagian dari kebutuhan daging sapi harus diimpor. Kondisi yang demikian menunjukkan adanya peluang untuk pengembangan usaha budidaya ternak sapi potong lokal. Oleh karena itu akhir-akhir ini telah banyak berkembang usaha penggemukan sapi potong yang dilakukan oleh para peternak maupun kelompok tani di Indonesia. Untuk peternak kecil, yang kebanyakan ialah petani di pedesaan, usaha penggemukan sapi ini merupakan alternatif yang biasa dilakukan untuk menambah pendapatan keluarga.

Sistem pemeliharaan dilakukan pola intensif dimana penyediaan pakan dilakukan oleh peternak (cut and carry). Pakan yang diberikan berupa hijauan yang bersumber dari tanaman naungan berupa leguminosa pohon (lamtoro dan gliricidia) ataupun yang dikembangkan pagar hidup sebagai pakan utama yang tersedia tiap hari. Untuk memenuhi kebutuhan hijauan pakan berbagai usaha telah banyak 
dilakukan seperti integrasi padi ternak atau pemanfaatan lahan perkebunan kelapa, perkebunan karet, kakau dan tanaman pangan (Priayanto, 2008).

Keberhasilan pembangunan peternakan yang hanya diukur dengan meningkatnya produksi usaha tani ternak sapi potong harus lebih dikembangkan lagi yaitu dengan memberdayakan petani ternak agar pendapatan dan kehidupannya meningkat. Dalam hal ini petani ternak sebagai subyek, sedangkan ternak sebagai obyek pembangunan yang harus ditingkatkan produksinya; adapun lahan, air sebagai basis ekologi budidaya harus dijaga kesuburannya sedangkan teknologi adalah sebagai alat untuk meningkatkan efisiensi yang harus selalu diperbaharui sesuai dengan kebutuhan. Dengan demikian pembangunan peternakan harus dikembangkan menjadi industri biologis yang dikendalikan manusia (Bambang, 2004).

Kecamatan Bintauna memiliki lahan yang cukup luas untuk sektor pertanian. Hal ini mengindikasikan Kecamatan Bintauna mempunyai potensi lahan yang luas untuk pengembangan ternak sapi potong. Luas lahan pertanian yang tersedia tersebut sangat menunjang dalam penyadiaan pakan bagi ternak sapi potong. Data pra survey yang diperoleh, sebagian peternak di Kecamatan Bintauna melakukan usaha penggemukan sapi potong dengan berhimpun didalam kelompok tani. Salah satu kelompok tani yang ada di Kecamatan Bintauna adalah "Sumber Hidup Sejati”. Ternak sapi milik anggota kelompok tani "Sumber Hidup Sejati” dikumpulkan didalam kandang yang dibuat oleh kelompok dan digemukkan selama 6 bulan.

Berdasarkan latar belakang di atas maka permasalahanya berapa Break Even Point (BEP) yang dicapai usaha penggemukan sapi potong "Sumber Hidup Sejati” dengan produktivitas dan populasi penggemukan sapi yang ada. Break Even Point (BEP) diartikan sebagai suatu titik atau keadaan dimana perusahaan di dalam operasinya tidak memperoleh keuntungan dan tidak menderita kerugian, dengan kata lain, pada keadaan itu keuntungan atau kerugian sama dengan nol. Analisa break even point ini menganalisis hubungan antara biaya produksi, penerimaan dan volume produksi.

Rumusan masalah dalam penelitian ini adalah:

1. Berapa besar biaya yang digunakan oleh kelompok dalam mengelolah usaha ternaknya.

2. Pada posisi mana usaha penggemukan sapi potong kelompok tani "Sumber Hidup Sejati” tidak mengalami keuntungan ataupun kerugian (Break Even Point). 
Adapun yang menjadi tujuan dari penelitian ini adalah:

1. Untuk mengetahui berapa besar biaya produksi yang diperoleh usaha tarnak sapi potong di kelompok tani "Sumber Hidup Sejati”.

2. Untuk mengetahui Break Even Point (BEP) usaha ternak sapi potong pada kelompok tani "Sumber Hidup Sejati".

\section{METODE PENELITIAN}

Penelitian ini dilakukan di Desa Huntuk Kecamatan Bintauna Kabupaten Bolaang Mangondow Utara pada Kelompok Tani “Sumber Hidup Sejati”. Metode yang digunakan dalam penelitian ini adalah metode studi kasus. Studi kasus merupakan pengujian secara rinci terhadap sasaran penelitian dan ditelaah secara mendalam sebagai suatu totalitas sesuai dengan tujuan penelitian (Aries, 2008). Data yang diperoleh bersumber dari data primer dan data sekunder. Data primer diperoleh langsung dari responden melalui wawancara dengan menggunakan kuesioner. Data sekunder diperoleh dari instansi yang terkait dengan penelitian ini.
Responden dalam penelitian ini adalah anggota kelompok tani ternak sapi "Sumber Hidup Sejati ". Analisis data yang digunakan adalah analisis Break Even Point (BEP). Perhitungan biaya tetap dalam penelitian ini dihitung dari biaya penyusutan kandang dan peralatan yang digunakan dengan rumus penyusutan menurut (Baridwan, 2004), seperti pada persamaan (1).

Penyusutan per Tahun =

$$
\frac{\text { Nilai Beli-Nilai Sisa }}{\text { Umur Pakai }}
$$

Analisis Break Even Point (BEP) digunakan untuk mengetahui hubungan antara variabel didalam kegiatan perusahaan yakni biaya produksi, volume produksi dan keuntungan yang diperoleh perusahaan. Rumus BEP secara matematis yang digunakan mengacu dari Riyanto (2001) seperti pada persamaan (2).

$$
\begin{aligned}
& \text { BEP }(\text { Harga/Rp })= \\
& \frac{\text { Biaya Tetap }}{1-\frac{\text { Biaya Variabel }}{\text { Harga per ekor }}}
\end{aligned}
$$

BEP $($ Jumlah/Unit $)=$ Biaya tetap

Harga per ekor-Biaya Variabel per Unit 


\section{HASIL DAN PEMBAHASAN}

Desa Huntuk merupakan salah satu desa yang berada di Kecamatan Bintauna Kabupaten Bolaang Mongondow Utara. Di daerah ini terdapat usaha peternakan penggemukan sapi potong yang dikelolah oleh peternak yang tergabung dalam kelompok usaha tani "Sumber Hidup Sejati”. Usaha ini merupakan usaha yang dikelola oleh para peternak. Usaha penggemukan sapi potong dimulai tahun 2012 diatas lahan seluas 20 ha dengan jumlah anggota kelompok sebanyak 13 orang dengan bapak Moh. Iman Alamri sebagai ketua kelompok.

Berdasarkan perkembangan usaha yang ada menunjukkan kelompok tani "Sumber Hidup Sejati" sedikit sulit memperoleh sapi bakalan untuk di gemukkan, maka sapi bakalan diperoleh dari daerah sekitar yaitu dari peternakpeternak yang berada di Kecamatan Bintauna dan Kecamatan sekitar seperti Kecamatan Sangkub, Kaidipang, Pinoguluman, Bolangitang Timur, dan lain-lain. Jenis bakalan ternak sapi potong adalah sapi bali dan peranakan ongole (PO).

\section{Biaya Produksi, Penerimaan dan}

\section{Keuntungan}

Menurut Soekardono (2009), biaya produksi secara teori terdiri dari biaya tetap dan biaya variabel. Biaya tetap adalah biaya yang dikeluarkan setiap tahun yang besarnya tidak berpengaruh langsung terhadap jumlah output yang dihasilkan. Biaya tetap yang dikeluarkan oleh kelompok tani "Sumber Hidup Sejati" meliputi sewa tanah, listrik, penyusutan, biaya tetap dan biaya variabel.

a. Biaya Sewa Tanah

Luas tanah yang disewa oleh "Sumber Hidup Sejati" adalah $15 \mathrm{Ha}=150.000$ $\mathrm{m}^{2}$, besarnya biaya sewa tanah yaitu $\mathrm{Rp}$. 200.000/6 bulannya. Sehingga total pengeluaran untuk sewa tanah pada setiap tahunnya yaitu sebesar Rp. $200.000 \times 2=$ Rp. $400.000 /$ tahun.

b. Biaya Listrik

Berdasarkan hasil wawancara besarnya total biaya listrik yaitu Rp. $30.000 /$ bulan $\times 12$ bulan $=\mathrm{Rp}$. 360.000/tahun.

c. Biaya Penyusutan

Penyusutan mencari laba dan rugi terdapat komponen biaya penyusutan yang didapat dari investasi. Besarnya biaya penyusutan per tahun yaitu $\mathrm{Rp}$. 11.520.000.

d. Biaya Tetap

Total biaya tetap Kelompok Tani "Sumber Hidup Sejati" adalah sebesar Rp. 6.280.000.

e. Biaya Variabel

Total biaya variabel Kelompok Tani "Sumber Hidup Sejati" adalah sebesar Rp. 93.444.000. 
Penerimaan yang diperoleh kelompok "Sumber Hidup Sejati” sebesar Rp. 105.000.000 dengan jumlah pemeliharaan ternak sapi 14 ekor. Harga jual dari ternak sapi sebesar Rp. 7.5000.000/ekor adalah rata-rata harga yang dijual.

Keuntungan Kelompok Tani "Sumber Hidup Sejati" untuk jumlah ternak sapi sebanyak 14 ekor memperoleh keuntungan sesuai hasil penelitian sebesar Rp. 12.276.000.

\section{Analisis Titik Impas (Break Even Point)}

Analisis Break Even Point merupakan salah satu teknis analisis ekonomi yang berguna dalam hubungan biaya variabel total (TVC) dan biaya tetap total (TFC) terhadap output produksi atau ukuran-ukuran lain dalam aktifitas bisnis dan industri (Gaspersz, 2002). Analisis BEP ini dilakukan dengan pertimbangan bahwa usaha penggemukan sapi potong sudah beroperasi sekitar 8 tahun. Berdasarkan kondisi ini maka dibutuhkan pegkajian berapa usaha tersebut mengalami pulang pokok/titik impas.

Analisis Break Even Point (BEP) digunakan untuk mengetahui hubungan antar variabel didalam kegiatan perusahaan yakni biaya produksi, volume produksi dan keuntungan yanga diperoleh perusahaan. Riyanto (2001), rumus matematis yang digunakan adalah:

$$
\operatorname{BEP}(\mathrm{Rp})=\frac{\text { Biaya Tetap }}{1-\frac{\text { Biaya Variabel }}{\text { Penjualan }}}
$$

$\operatorname{BEP}($ ekor $)=$ Total Biaya tetap

Harga jual per ekor-Biaya Variabel/kuantitas produksi (ekor)

BEP Penerimaan $(\mathrm{Rp})=$

$$
\begin{aligned}
& \frac{6.280 .000}{1-\frac{86.444 .000}{105.000 .000}} \\
& =\frac{6.280 .000}{1-0.82} \\
& =34.888 .889
\end{aligned}
$$

Berdasarkan hasil analisis BEP harga dipeoleh nilai 34.888.889. Artinya usaha ternak sapi potong pada kelompok tani "Sumber Hidup Sejati” mencapai pulang pokok pada saat memperoleh penerimaan sebesar Rp. 34,888,889,-.

$$
\begin{aligned}
\operatorname{BEP}(\text { ekor }) & =\frac{6.280 .000}{7.500 .000-\frac{86.444 .000}{14}} \\
& =\frac{6.280 .000}{1.325 .429} \\
& =4,74
\end{aligned}
$$

Berdasarkan hasil analisis BEP volume diperoleh nilai BEPnya sebesar 4,74. Artinya usaha ternak sapi potong pada kelompok tani "Sumber Hidup Sejati" 


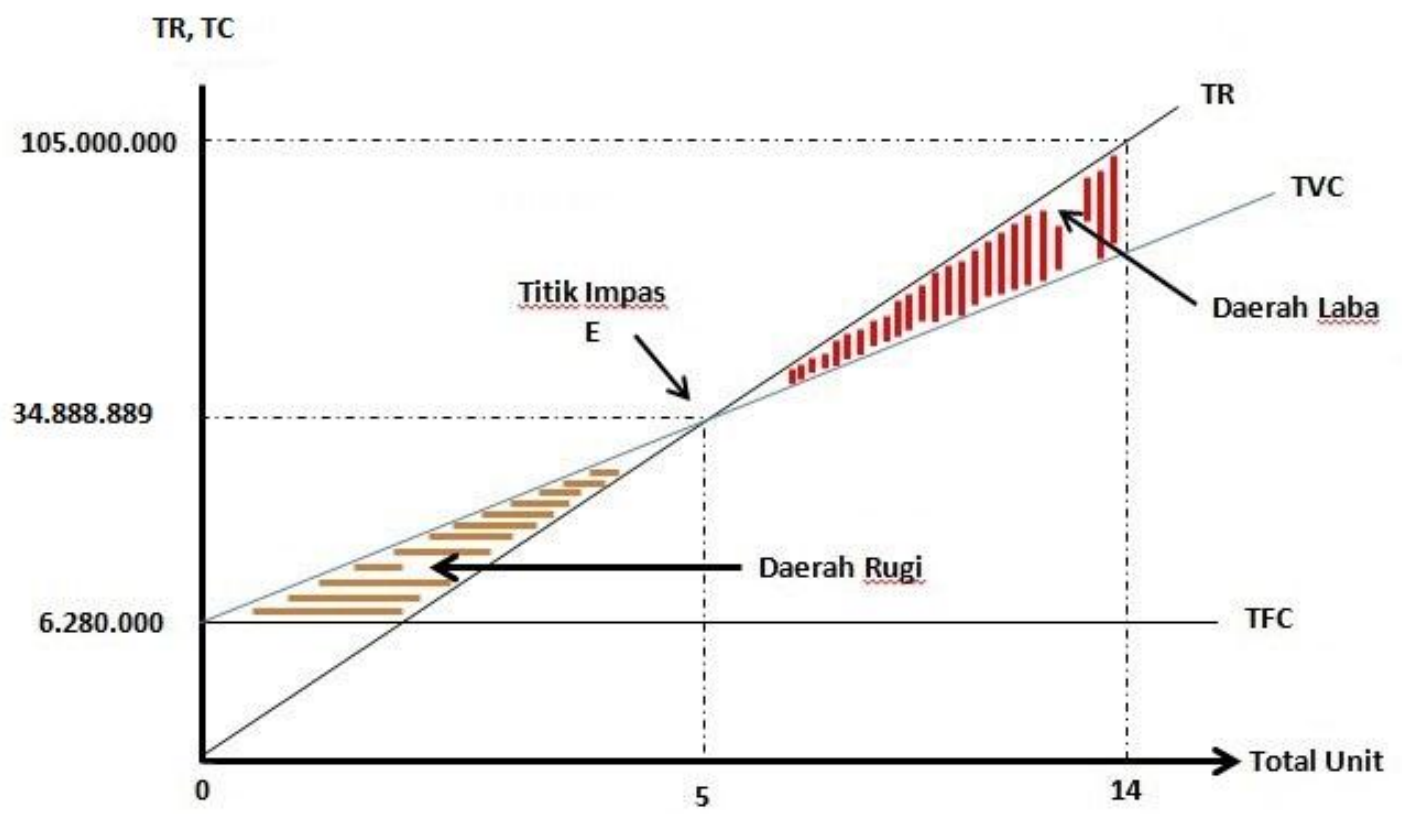

\section{Gambar 1. Grafik Break Even Point}

Keterangan :

$\mathrm{TR}=$ Total Revenue

$\mathrm{TC}=$ Total Cost

TVC = Total Variabel Cost

TFC $=$ Total Fixed Cost

mencapai pulang pokok apabila atau rugi pada tingkat penjualan tertentu, memelihara sapi potong sebanyak 5 ekor.

Kondisi nilai BEP penerimaan dan dan titik BEP. Berdasarkan Gambar 1 dijelaskan sebagai berikut.

volume dengan menggunakan rumus BEP menurut Riyanto (2001), sesuai dengan perhitungan atau analisis Total Revenue (TR) dan Total Variabel Cost (TVC) dengan menggunakan grafik. Grafik BEP dapat dilihat pada Gambar 1.

Grafik BEP dapat diketahui nilai penjualan, kuantitas penjualan,biaya variabel, biaya tetap, laba marginal, laba

a. Garis vertikal menunjukan biaya dan juga hasil penjualan total dalam rupiah atau sebesar Rp. 105.000.000,- dan biaya sebesar Rp. 92.724.000,-

b. Garis horizontal menunjukan kuantitas yang dijual. Oleh karena harga produk bersifat tetap maka sumbu $\mathrm{X}$ juga dapat menunjukan penjualan dalam rupiah atau pada penjualan 14 ekor. 
c. Perusahaan berkapasitas maksimum 14 unit, berarti penjualan maksimum Rp. 105.000.000,-

d. Biaya variabel ditarik dari titik $\mathrm{Rp}$. 6.280.000 Kekanan atas ketitik Rp. 86.444.000,- (yaitu angka yang diperoleh dari biaya tetap Rp. 6.280 .000 Ditambah biaya variabel $\mathrm{Rp}$. 86.444.000) Pada penjualan Rp. 105.000.000.

Pertemuan antara garis biaya total dan garis penjualan, yaitu titik $\mathrm{E}$, disebut sebagai titik BEP (break event point) dari titik ini ditarik garis lurus kesumbu $\mathrm{Y}$ akan diperoleh nilai penjualan BEP yaitu Rp. 34.888.889, dan biaya total juga $\mathrm{Rp}$. 86.444.000. Dari titk BEP ditarik garis lurus ke sumbu $X$ akan diperoleh kuantitas penjualan BEP yaitu 5 unit. dari titik BEP kekiri terlihat segitiga yang menunjukan daerah rugi (loss area) dan kekanan terlihat segitiga yang menunjukan daerah laba (profit area).

\section{KESIMPULAN}

Berdasarkan hasil dan pembahasan di atas, dapat disimpulkan beberapa hal sebagai berikut:

1. Biaya produksi usaha penggemukkan sapi potong pada kelompok tani

"Sumber Hidup Sejati" dengan
pemeliharaan 14 ekor yaitu Rp.
92.724.000,-

2. Usaha penggemukan sapi potong dalam penelitian ini menunjukkan nilai BEP penerimaan yaitu sebesar Rp. 34.888.889,-- dan BEP produksi sebesar 4,74 .

\section{DAFTAR PUSTAKA}

Abdullah, L., P.D.M.H. Karti dan S. Hardjoewignyo. 2005. Reposisi tanaman pakan dalam kurikulum Fakultas Peternakan Pros. Lokakarya Nasional Tanaman PakanTernak. Bogor

Aries, Erna Febru. 2008. Metode Penelitian Studi Kasus. http://ardhana12.wordpress.com/.

(Diakses tanggal 5 September 2016).

Bambang, S. 2004. Peran Usaha Peternakan Sapi potong Dalam Pembangunan Agribisnis. University Press, Semarang.

Dinas Pertanian, Peternakan, Perkebunan \& Kehutanan Kabupaten Bolaang Mongondow Utara. 2012. Laporan Tahunan Dinas Pertanian, Peternakan, Perkebunan \& Kehutanan Kabupaten Bolaang Mongondow Utara.

Gazpersz, V. 2002. Pedoman Penyusunan Rencana Bisnis. PT Gramedia Pustaka utama. Jakarta. 
Priyanto, D. 2008. Model Usahatani integrasi ternak sapi dalam upaya peningkatan pendapatan petani. Wartazoa.

Riyanto, Bambang. 2001. Dasar-dasar Pembelanjaan Perusahaan. Yogyakarta:BPFE.

Soekartawi. 2003. Agribisnis, Teori dan Aplikasinya. Penerbit PT. Raja Grafindo Persada. Jakarta. 